\title{
KRIMINALISASI TERHADAP PEKERJA SEKS KOMERSIAL MELALUI ONLINE DALAM PEMBAHARUAN HUKUM PIDANA
}

\author{
I Gede Yoga Pratama, Anak Agung Sagung Laksmi Dewi, I Made Minggu Widyantara \\ Fakultas Hukum Universitas Warmadewa, Denpasar-Bali, Indonesia \\ igedeyogapratama1201@gmail.com, laksmiidewi29@gmail.com, Mademinggu21@gmail.com
}

\begin{abstract}
Abstrak
Pelacuran merupakan suatu perilaku yang secara terbuka menyerahkan diri pada perzinahan tanpa ada ikatan perkawinan, saat ini prostitusi dengan mudah dicari di berbagai media sosial. Peraturan terkait komersial telah diatur dalam KUHP, UU No. 19 Tahun 2016 tentang Informasi dan Transaksi Elektronik, UU No. 44 Tahun 2008 tentang Pornografi, UU No. 21 Tahun 2007 tentang Tindak Pidana Perdagangan Orang. Penelitian ini bertujuan untuk mengkaji pengaturan hukum pidana pekerja seks komersial melalui online menurut hukum positif dan mengungkap sanksi pidana terhadap pekerja seks komersial online di masa yang akan datang. Penelitian ini dirancang dengan penelitian hukum normatif, dengan pendekatan Legislatif. Bahan hukum yang digunakan adalah bahan hukum primer dan bahan hukum sekunder. Data dikumpulkan menggunakan studi dokumentasi dan studi kepustakaan, kemudian dianalisis dengan teknik interpretasi sistematis. Hasil penelitian menunjukkan bahwa sanksi bagi mucikari sebagaimana diatur dalam KUHP, UU No. 21/2007, UU No. 44/2008, dan UU no. 19/2016, dan hanya pasal 284 KUHP tentang perzinaan yang dapat menjerat PSK dan pelanggan jika sudah berkeluarga dan untuk sanksi pidana bagi pekerja seks komersial di kemudian hari terdapat dalam pasal 425 sampai dengan 428 R KUHP.
\end{abstract}

Kata Kunci: Hukum Positif, Sanksi Pidana, Prostitusi Online

\begin{abstract}
Prostitution is behavior that is openly subject to adultery without any marriage bond. Nowadays prostitution is easy to find on various social media. Commercial-related regulations have been regulated in the Criminal Code, Law no. 19 of 2016 concerning Information and Electronic Transactions, Law no. 44 of 2008 concerning Pornography, Law no. 21 of 2007 concerning the Crime of Human Trafficking. This study aimed to examine the criminal law regulation of online sex workers according to positive law and uncover criminal sanctions against online sex workers in the future. This study was designed using normative legal research, with a Legislative approach. The legal materials used were primary legal materials and secondary legal materials. Data were collected using documentation study techniques and literature studies, then analyzed using systematic interpretation techniques. The results of the study indicated that sanctions for pimps are regulated in the Criminal Code, Law no. 21/2007, Law no. 44/2008, and Law no. 19/2016, and only article 284 of the Criminal Code concerning adultery that can ensnare prostitutes and customers if they have a family, and criminal sanctions for commercial sex workers in the future are contained in articles 425 to 428 of the Draft Criminal Code.
\end{abstract}

Keywords: Positive Law, Criminal Sanctions, Online Prostitution

\section{PENDAHULUAN}

Khalayak sudah mengganti uang serta benda menggunakan hubungan seks hampir sejak berabadabad yang lalu. sedari rancangan peralihan tersebut mulai terkenal, pada saat itu tentunya prostitusi mulai hadir ditengah masyarakat di dunia. Pekerjaan ini diprediksi telah lahir sedari awal tahun masehi sampai-sampai bisa jadi jauh sebelum tersebut. Prostitusi di Indonesia diyakini perihal suatu kriminal kepada budi pekerti ataupun akhlak serta berseberangan dengan aturan hukum (Puspita, 2015). aksi prostitusi adalah salah satu wujud anomali sosial yang digunakan sedari zaman dahulu hingga sekarang. Kata pelacur pada awalnya bermula dari pada istilah dalam bahasa latin yaitu prostitution yang dimana selanjutnya diolah dengan Bahasa Indonesia yaitu prostitusi (Kamasa, 2014). Maka oleh sebab itu dengan demikian bisa di definisikan yang dimana prostitusi merupakan sebagai kegiatan secara langsung atau terbuka yang dimana pelakunya tersebut memasrahkan 
pribadinya ke dalam perzinahan dengan tidak dimilikinya suatu ikatan suci yaitu perkawinan (Alam $\&$ Amir ilyas, 2018).

Pengertian PSK adalah seseorang memasarkan tubuhnya atau jasanya untuk melangsungkan suatu aktivitas terlarang yang dimaksudkan guna peningkatan taraf ekonomi dari PSK tersebut . Sedangkan online merupakan sebutan pada waktu seseorang selagi terkoneksi dengan dunia maya, mulai terkoneksi bersama aplikasi media social seseorang, surat elektronik serta beraneka macam akun lainnya yang orang tersebut gunakan dengan internet. Jadi, pekerja seks komersial dengan sarana online merupakan seorang yang menjual dirinya dengan melakukan hubungan seks yang berhubungan dengan internet atau dunia maya, yang dimana hal tersebut bertujuan untuk meningkatkan ekonominya. Biasanya pekerja seks komersial melalui online ini menjual dirinya melalui media online, banyak alternative media online yang digunakan perempuan untuk menjajakan dirinya (Sumenge, 2013).

Prostitusi online adalah ancaman untuk moralitas bangsa. Jika merujuk pada KUHP kemudian belum terdapat satu aturan pun yang menertibkan secara eksklusif. Dalam pasal 296 dan pasal 506 belum diperuntukkan pada PSK. Akan tetapi aturan-aturan berikut hanya diperuntukkan terhadap pihak germo ataupun mucikari serta pihak calo. Pihak germo serta calo bisa dihukum jika dikarenakan kegiatan mereka telah terpenuhinya poin-poin dalam pasal 296. Oleh sebab itu belum pas rasanya apabila melangsungkan pencegahan praktek prostitusi dengan memakai aturan yang terdapat pada KUHP, hukum tentunya tidak bisa kembali mewadahi kasus praktik prostitusi ini. Oleh sebab itu maka kepolisian tentunya susah untuk menghukum PSK dan pelanggannya tersebut, dikarenakan tidak adanya aturan pidana yang mengaturnya. Selain aturan mengenai pelacuran secara online terdapat pada KUHPidana, aturan yang berkaitan perihal prostitusi online berikut pula hadir pada ketentuan UU RI No. 19/2016 perihal UU ITE, UU No. 44/2008 perihal Pornografi, UU No. 21/2007 perihal TPPO.

Tindak pidana pada hukum pidana Belanda yang diindonesiakan yang artinya adalah kriminalisasi. Kendatipun kata berikut tercantum pada Wvs Belanda maupun berlandaskan pada asas konkordansi kata ini tentunya juga sah dalam KUHP. Namun belum terdapat penggambaran formal perihal tentang definisi dari kriminalisasi itu sendiri. Oleh sebab itu, beberapa ahli hukum berniat guna menyampaikan pengertian dari kata tersebut, akan tetapi sampai waktu berikut tidak dimilikinya keserupaan suatu doktrin perihal definisi dari kriminalisasi iru sendiri (Chazawi, 2002). Dari uraian latar belakang masalah tersebut, oleh sebab ingin melakukan penelitian yang bertujuan untuk mengkaji pengaturan hukum pekerja seks komersial melalui online menurut hukum positif dan mengungkapkan sanksi pidana terhadap pekerja seks komersial melalui online dimasa yang akan datang.

\section{METODE PENELITIAN}

Tipe penelitian ini menggunakan penelitian hukum normatif dengan pendekatan perundangundangan. Sumber bahan hukum yang diterapkan dalam observasi berikut terdapat tiga bahan hukum yaitu bahan hukum primer meliputi peraturan Perundang-undangan yang berlaku di Indonesia dan bahan hukum sekunder meliputi bahan hukum tertulis berupa literatur jurnal yang ditulis oleh para ahli serta bahan hukum tersier meliputi KBBI maupun kamus bahasa latin dan bahasa Inggris, Teknik pengumpulan bahan hukum melalui teknik studi dokumentasi dan studi kepustakaan, dan analisis bahan hukum yang dilakukan yaitu dianalisis dengan teknik interpretasi sistematis (Sulistyowati \& Shidarta, 2009).

\section{HASIL DAN PEMBAHASAN}

\section{Pengaturan Hukum Pidana Pekerja Seks Komersial Melalui Online Menurut Hukum Positif}

Kemajuan dibidang teknologi dan informatika berikut berketerkaitan pada social change yang tertuju terhadap terciptanya bangsa yang modern. Satjipto, (2000) bahwasannya pada setiap aktivitas khalayak terdapat aspek yang bisa digunakan menjadi penyebab timbulnya satu metamorfosis di tengah masyarakat akan tetapi pada transisi penerapan efek dari teknologi terbarukan saat ini banyak diistilahkan menjadi satu diantara alasan terciptanya gejala social change. Permasalahan PSK di Indonesia benar-benar berseberangan pada aturan hukum utamanya adalah aturan agama, aturan 
kesopanan serta aturan kesusilaan (Dewi, 2012). Dalam hal prostitusi online pada aturan hukum positif yaitu KUHPidana, UU No. 19/2016 perihal Informasi dan Transaksi Elektronik dan UU No. 44/2008 perihal Pornografi. Dalam hal hukuman yang tercantum dalam KUHPidana dan Undangundang berikut menjelaskan hukuman terhadap para germo atau mucikari saja. KUHPidana serta Undang-undang itu belum terdapat yang mengatur perihal aturan pemidanaan yang dilakukan oleh pengguna layanan PSK dalam tindak pidana prostitusi online. Banyak terdapat referensi mengenai ketentuan perihal pengguna jasa SK di Indonesia adalah sebagai berikut

1. Kitab Undang-undang hukum pidana dapat kita dilihat pada Pasal 295, Pasal 296, Pasal 297 serta Pasal 506 KUHPidana.

2. Undang-undang Nomor 19 Tahun 2016 tentang Informasi dan Transaksi Elektronik Dapat kita dilihat pada Pasal 27 Undang-undang Nomor 19 Tahun 2016.

3. Undang-undang Nomor 44 Tahun 2008 Tentang Pornografi Dapat kita dilihat pada Pasal 30, Pasal 33, Pasal 35 Undang-undang Nomor 44 Tahun 2008.

4. Undang-undang Nomor 21 Tahun 2007 tentang Tindak Pidana Perdagangan Orang (UU TPPO) Dapat kita dilihat pada Pasal 2 ayat (1) Undang-undang Nomor 21 Tahun 2007.

PSK sering menggunakan media sosial seperti Facebook, Twitter serta yang terbaru saat ini ialah melalui aplikasi Michat, Tinder serta Tantan guna memasarkan ataupun mempublikasikan dirinya terhadap pria yang ingin memenuhi nafsu birahinya. PSK biasanya mengambil suatu keputusan guna memasarkan dirinya pada aplikasi media online dikarenakan lebih sederhana serta terjamin, belum memiliki masalah pada aturan hukum dikarenakan tidak menjajakan dirinya di jalanan serta lebih mudah untuk bertatap muka langsung dengan pria tanpa melewati perantara dan bahkan PSK bisa menaruh harga dahulu sebelum terjadinya kesepakatan bersama.

Prostitusi online berikut biasa dipanggil dengan nama call girl. Di Indonesia pelacuran dalam hal berikut lazimnya digunakan dengan perantara misalnya mucikari, manajer, mami dan serempak aktivitas seksual berikut berada dibawah naungan perantara yang tadi disebutkan serta semakin canggihnya suatu teknologi lazimnya cara mengorder PSK tersebut memanfaatkan aplikasi online. Seperti memanfaatkan Facebook, WhatsApp, Twitter serta yang terbaru saat ini adalah melalui aplikasi Michat, Tinder serta Tantan. untuk mempromosikan. Satu diantara karakter khas pada pelacuran secara panggilan lazimnya jika melangsungkan suatu hubungan terlarang bukan dilaksanakan dalam wilayah-wilayah khusus saja namun selalu berpindah-pindah tempat atau lokasi.

Pada tahun 2016, Indonesia mengeluarkan Undang-undang Nomor 19 tahun 2016 tentang Informasi dan Transaksi Elektronik (ITE). Dalam Undang-undang ITE tersebut, diperoleh aturanaturan pada peraturan pidananya yang dengan mutlak menertibkan berkaitan perihal pertanggungjawaban pada pidana PSK. Diantaranya diatur dalam pasal 27 ayat (1) dan Pasal 45 ayat (1). berlandaskan pada Pasal 27 ayat (1) dan Pasal 45 ayat (1) UU No. 19/2016 perihal Informasi dan Transaksi Elektronik (ITE) tersebut, oleh sebab itu hukuman yang bisa dijeratkan terhadap PSK online adalah pidana penjara atau pidana denda (Setiady 2010). Dalam Undang-undang Nomor 19 Tahun 2016 tentang Informasi dan Transaksi Elektronik (UU ITE) berikut belum dipaparkan perihal sanksi pidana bagi pengguna layanan PSK pada tindak pidana prostitusi online. UU inipun belum bisa menangkap para pengguna layanan PSK online tersebut, dengan demikian aturan berikut belum pas dipakai guna memecahkan suatu persoalan mengenai prostitusi.

\section{Sanksi Pidana Terhadap Pekerja Seks Komersial Dengan Sarana Online Dimasa yang Akan Datang}

PSK ialah merupakan setiap pekerja yang bertujuan untuk menjalankan setiap kegiatan seks dengan bermaksud guna memperoleh upah dari yang sudah menggunakan pelayanan mereka berikut. Pada buku-buku yang lainnya pula menyebutkan bahwasannya definisi dari PSK adalah perempuan yang berprofesi mempromosikan tubuhnya terhadap pria yang memerlukan pemenuhan nafsu seksualnya serta perempuan tersebut memperoleh upah sebagai hak atas pelayanan yang diberikannya, dan tentunya perbuatan tersebut dilaksanakan diluar akad nikah atau berzinah (Purnomo, 1983). Ditinjau pada bagian kejiwaannya, terdapat sebagian aspek kejiwaan yang menjadikan pemicu perempuan menjadi PSK ialah yaitu aktivitas seks yang tidak seperti biasanya, memiliki jati diri yang lembek, memiliki Integritas yang kecil dan tidak meningkat, contohnya, ketidakmampuan melihat baik serta 
jahat, betul serta salah, dan hal-hal lainnya, mudah terhasut, mempunyai pola hidup mewah, artinya menahbiskan suatu kemewahan menjadikannya tujuan utama.

Dalam prostitusi online sendiri yang dimana dalam setiap aturan yang berlaku terdapat beberapa pula jenis sanksi pidana seperti pidana penjara, pidana kurungan dan pidana denda. Lalu jenis sanksi apa saja yang berlaku dalam prostitusi online yang diatur dalam KUHP, UU RI No. 19/2016 perihal ITE, UU RI No. 44/2008 perihal Pornografi, UU No. 21/2007 perihal TPPU adalah sebagai berikut:

\section{KUHPidana}

Dalam KUHPidana dapat kita temukan pasal-pasal yang menjerat pelaku prostitusi online khususnya untuk germo/mucikari dan jenis sanksi apa yang berlaku. Dalam Pasal 295 KUHPidana sanksi yang dijerat ialah dengan sanksi pidana penjara, Pasal 296 KUHPidana jenis sanksi yang dapat dijerat ialah sanksi pidana penjara dan pidana denda, Pasal 297 KUHPidana jenis sanksi yang bisa dijerat ialah berupa sanksi pidana penjara, dan yang terakhir dalam pasal 506 KUHPidana jenis sanksi yang bisa dijerat ialah jenis sanksi pidana kurungan.

2. Undang-undang Nomor 19 Tahun 2016 tentang Informasi dan Transaksi Elektronik (UU ITE)

Didalam Undang-undang Nomor 19 Tahun 2016 tentang Informasi dan Transaksi Elektronik (UU ITE) tersebut dapat ditemukan pasal yang menjerat pelaku prostitusi online serta jenis sanksi apa yang dapat dijerat terhadap pelaku prostitusi online adalah dalam Ketentuan Pasal 27 Ayat (1) dalam Undang-undang tersebut jenis sanksi pidana yang dapat dijeratkan ialah berupa sanksi pidana penjara dan sanksi pidana denda.

3. Undang-undang Nomor 44 Tahun 2008 tentang Pornografi

UU No.44/2008 perihal Pornografi berikut dapat ditemukan pasal-pasal yang bisa menjerat pelaku prostitusi online ialah dapat kita temukan dalam ketentuan Pasal 30 yang dimana dalam pasal berikut jenis sanksi yang dapat dijeratkan ialah berupa sanksi pidana penjara dan sanksi pidana denda, Pasal 33 jenis sanksi yang bisa dijeratkan ialah sanksi pidana penjara dan pidana denda, dan yang terakhir dalam Pasal 35 jenis sanksi yang dapat dijeratkan ialah berupa sanksi pidana penjara dan pidana denda.

4. Undang-undang Nomor 21 Tahun 2007 tentang Tindak Pidana Perdagangan Orang (TPPO)

UU No. 21/2007 perihal TPPO ini dapat kita temukan pasal yang dapat menjerat pelaku prostitusi online adalah di dalam ketentuan pasal 2 Ayat (1) dalam UU ini serta jenis sanksi yang berlaku ialah berupa sanksi pidana penjara dan pidana denda.

Pada Rancangan Undang-undang kitab Undang-undang Hukum Pidana Tahun 2019 ketentuan perihal PSK tentunya belum terlalu banyak yang berganti pada yang tercantum dalam Kitab Undangundang Hukum Pidana yang berjalan pada waktu ini. RUU KUHP tentunya hanya menertibkan kegiatan mucikari yang dengan gampang melaksanakan kegiatan cabul antara orang lain terhadap orang lain. Sebaliknya kegiatan pihak lain yang ikut serta pada pelaksanaan prostitusi misalnya germo serta pengguna jasa tentunya tidak terdapat adanya suatu ketentuan yang bisa menghukum mereka. Ketentuan yang menertibkan aktivitas prostitusi diatur pada bagian kelima perihal perbuatan cabul serta pada paragraf 2 perihal memudahkan Percabulan dan Persetubuhan, yang terdapat dalam pasal 425 hingga pasal 428 RUU KUHP 2019.

Sudah sepatutnya pula peran pemerintah ikut andil agar dunia prostitusi di Indonesia berkurang setiap tahunnya dengan cara membuat suatu aturan payung hukum yang jelas terutama bagi PSK serta Pelanggan yang tidak ada satupun aturan yang mengaturnya serta pengawasan ketat di dalam setiap aplikasi online baik facebook, whatsapp, michat, tantan, tinder dan lain sebagainya diawasi ketat agar perempuan bangsa indonesia tidak menjajakan dirinya melalui media sosial ataupun bahkan juga pengawasan keliling di setiap jalanan agar tidak ada perempuan yang menjajakan dirinya di jalanan. Agar terciptanya suasana seperti yang dijelaskan didalam sila ke 2 dari Pancasila yaitu kemanusiaan yang adil dan beradab .

\section{SIMPULAN DAN SARAN}

\section{Simpulan}

Berdasarkan analisis data diketahui bahwa aturan mengenai prostitusi online di luar KUHP ditemukan dalam Pasal 2 ayat (1) UU No. 21 Tahun 2007 tentang Tindak Pidana Perdagangan Orang, Pasal 30 Pasal 33 Pasal 35 UU No. 44 Tahun 2008 tentang Pornografi, dan Pasal 27 UU No. 19 Tahun 2016 
tentang Informasi dan Transaksi Elektronik, akan tetapi dengan mutlak pekerja seks komersial tersebut bisa dijatuhi pertanggungjawaban pidana memanfaatkan Undang-undang ITE karena Undang-undang tersebut bersamaan berlangsungnya suatu asas yang dinamakan asas lex specialis derogate legi generalis. Sanksi pidana terhadap pekerja seks komersial melalui online menurut hukum positif, mengenai pengaturan prostitusi dalam KUHP terdapat dalam Pasal 295 beserta hukuman penjara dalam waktu empat tahun, pasal 296 dengan hukuman penjara selama satu tahun empat bulan atau denda 15 ribu rupiah, Pasal 297 beserta hukuman penjara selama enam tahun, dan Pasal 506 dengan hukuman penjara selama satu tahun.

\section{Saran}

Adapun saran yang diberikan berkaitan dengan simpulan dalam penelitian ini yaitu Kepada pembuat aturan Perundang-undangan baik Presiden maupun DPR hendaknya membuat suatu aturan ketentuan pidana secara eksplisit atau adanya aturan yang jelas mengenai prostitusi yang dilakukan oleh pelanggan demi terciptanya suatu kepastian, keadilan, dan kemanfaatan hukum bagi masyarakat Indonesia. Diharapkan agar lembaga pembentuk Undang-undang baik Presiden maupun DPR guna menginovasi suatu peraturan undang-undang yang ada yang menertibkan perihal pelacuran pada pelanggan serta pada pekerja seks komersial (PSK) di Indonesia pada masa yang akan datang dengan demikian pada hal penertibannya, pemeliharaannya serta penumpasannya suatu aktivitas pelacuran berikut di Negara Indonesia tentunya lebih efisien serta menyeluruh.

\section{DAFTAR PUSTAKA}

Alam, A. S., \& Amir ilyas. (2018). Kriminologi Suatu Penganta. Jakarta. Gramedia Pustaka.

Chazawi, A. (2002). Stelsel Pidana, Tindak Pidana, Teori-teori Pemidanaan\& Batas Berlakunya Hukum Pidana Bagian I. Raja Grafindo Persada: Jakarta.

Dewi, B. (2012). Cyber Prostitusi. Udayana Press: Denpasar.

Kamasa, F. (2014). Kejahatan Kerah Putih Kontraterorisme dan Perlindungan Hak Konstitusi Warga Negara dalam Bidang Ekonomi. Jurnal Konstitusi, 11(4), 782-804.

Purnomo, T. (1983). Membedah Dunia Pelacuran Surabaya kasus kompleks pelacuran Dolly. Grafiti pers: Jakarta.

Puspita, Y. (2015). Pemanfaatan New Media dalam Memudahkan Komunikasi dan Transaksi Pelacur Gay. Jurnal Pekomnas, 18(3), 203-212.

Satjipto, R. (2000). Ilmu Hukum. Citra Aditya Bakti.

Sulistyowati, \& Shidarta. (2009). Metode Penelitian Hukum. Yayasan Pustaka Obor Indonesia.

Sumenge, M. M. (2013). Penipuan Menggunakan Media Internet Berupa Jualbeli Online. Jurnal Lex Crimen, 2(4), 102-112.

T, S. (2010). Pokok-pokok Hukum Penitensier Indonesia. Alfabeta: Bandung. 